\title{
The Art of Luxury: Sealy Brand Personality Identification
}

\author{
Rudy Prilto Lesmana ${ }^{1 *}$, Ferdinand Fransiscus Tanuwidjaja ${ }^{2}$, \\ Margaretha Margawati van Eymeren ${ }^{3}$ \\ ${ }^{123}$ Institut Komunikasi dan Bisnis LSPR, DKI Jakarta 10250, Indonesia
}

\begin{abstract}
A B S T R A C T
Sealy is one of luxury mattress brands in the global market that since 2013 strives to have a successful business in the Indonesia luxury mattress market. In Indonesia, Sealy competes directly with many top collection models from several other international mattress brands. To face the competition, Sealy needs brand personality. This research aims to identify Sealy's brand personality, which can be used as a guideline for the company when setting up its marketing communication plan. This research's methods are qualitative, and as desk research, the unit analysis are both product-related and non-product-related characteristics of Sealy that called drivers. This research constructs a category based on 42 traits, 15 facets, and 5 dimensions of Aaker's brand personality framework to analyze Sealy's specific brand drivers. The result is that Sealy main personalities are leader and upper class from competence and sophistication dimensions.
\end{abstract}

A R T I C L E I N F O

\author{
Article History: \\ Received : 13-01-2021 \\ Revised : 09-06-2021 \\ Accepted : 14-06-2021 \\ Published : 30-06-2021
}

Keywords:

Brand Personality

Marketing Communication

JEL: M31, M37

*Corresponding Author E-mail:

20210330057@lspr.edu

Copyright (C) 2021 Authors. This is an open access article distributed under the Creative Commons Attribution License (CC-BY-SA 4.0) which permits use, distribution and reproduction in any medium, provided the original work is properly cited \& ShareAlike terms followed.

\section{INTRODUCTION}

Ken Research reports in September 2017, that Indonesia mattress sales figure is very bright and will have annual double-digit growth for the next 4 years, and it will cross USD 350 million in 2021. The mattress demand growth is primarily caused by substantial investment in key segments such as residential housing and institutional sector including hospitals, hotels, and college hostels. Ken Research also found out that the increase of consumer expenditure by the rising awareness among the people, and sound sleep quality are the main reason for them to increase the needs for luxury mattresses in the Indonesian market.

The World Bank, in their published report on January 30, 2020 on "Aspiring Indonesia: Expanding the Middle Group", stated that Indonesia is having an amazing annual economic 
or gross domestic product growth with $5.6 \%$ rate over the past 50 years which as a result enabled the country to breed a middle income group of people. According to their report at least $20 \%$ from 52 million people in middle income group plus the whole top income group are able to buy luxury things such as car, insurance, lifestyle gadgets, abroad holiday travel, and luxury mattresses. That makes up a total of more than 10 million people in Indonesia as potential customers of luxury mattress products.

The growing of middle income group in Indonesia that provide abundant potential buyers together with the rising consumer awareness regarding the association between good sleep and a healthy mind and body created a demand for better quality and more expensive mattress. The situation excites mattress manufacturers to create and introduce more advanced products to be able to sell their products with higher price and higher margin. They educate new and updated techniques to improve the quality of mattresses to their potential consumer, which led to the incremental of production capacity of luxury mattress segment in Indonesia.

The market competition in this segment is getting though as they competing with each other to be the first company who launched the newest technology to lure consumers with the better mattress that can give reliable and durable support that can last for years, selection of firmness feel, new comfort level such as insensible motion of sleeping partner, indulgent fabrics that offer ultimate tenderness with cooling sensation and moisture control that can reduce the risk of having dust mites, and the very important one is the prestige of the brand they can use to impress other people. The retail price figure is the most common price range used in the mattress industry.

The mattress is categorized based on their offer to their consumer by communicating their premium price, best features, technology, best quality, aesthetics, and prestige image as a luxury mattress brand. This concept of luxury brands by Heine's, that define luxury brands as brands that are regarded as images in the minds of consumers that comprise associations about a high level of price, quality, aesthetics, rarity, extraordinariness, and a high degree of nonfunctional associations (Heine, 2012).

There are more than 10 mattress brands that exist and compete in the Indonesian luxury mattress market, such as Kingkoil, Serta, Springair, Therapedic, Simmons, Sealy, Lady Americana,

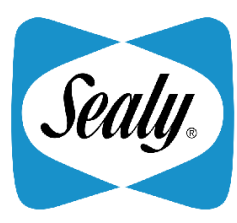

Sealy Posturepedic Collection (8 models): retail price range Rp. 22 million - Rp. 80 million

\section{Serta}

Celestial collection, Naturel collection, ipedic collection (6 models): retail price range Rp. 20 million - Rp. 55 million

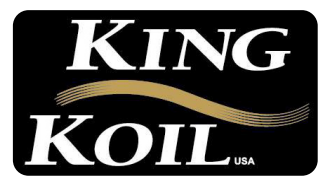

Signature gold series, Princess latex collection, and Noble latex collection ( 9 models): retail price range Rp. 20 million - Rp. 85 million

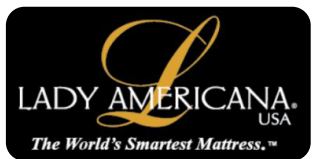

Splendorous collection (5 models): retail price range Rp. 20 million - Rp. 60 million

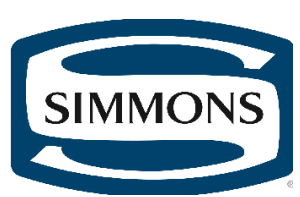

Backcare collection and Beautyrest collection (7 models): Rp. 20 million - Rp. 70 million

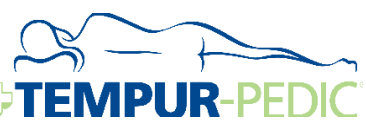

Original and Sensation collection (4 models): retail price range Rp. 40 million - Rp. 80 million

Figure 1. Price Range of 6 dominant International mattress brands in Indonesia 
Tempur, Dunlopillo, Slumberland, Curem, Dreamline, Silent Night, Lamborghini, etc. As the product availability of luxury mattress brands, with numerous functional product benefits, the market is growing and the competition level is getting high among the consumers' mind.

Sealy is one of luxury mattress brands in the global market that also strives to have a successful business in Indonesia luxury mattress market. According to Sealy Indonesia website, www.sealy.co.id, "Sealy" was taken from the name of a small town in Texas, USA, called Sealy, where the first Sealy mattress was made in 1881 by Daniel Haynes. Their mattresses quality are as good as in a very short period of time, the brand's tagline "mattress from Sealy" gets famous and becomes a trademark among the people as they scrambled to buy the mattresses. In the year 1950, the company officially introduced the Posturepedic mattress collection, the only mattresses in the industry that focused on correcting and support the back (spine) and they worked together with Orthopedic Surgeons on designing the mattress. The Posturepedic mattresses sold with the perceived very high retail price at that time which might have been the trendsetter of today's luxury mattress. ("Our Company," n.d.).

Sealy has a long history of making good quality mattresses, the company's flagship brand, Sealy, has been the number \#1 selling bedding brand in the USA market since 1970 for 30 years until 2010 and reclaims again that title in 2019 (Perry, 2020, June 8).

Further on their website, Sealy informs that they entered Indonesia market in 2013 and since then positioned the brand in the luxury mattress segmentation with their top 2 collections out of a total of 4 collections sold with retail price from Rp. 20 million up to Rp. 80 million per mattress. This makes the brand compete directly with many top collection models from several other international mattress brands such Dunlopillo, as the oldest luxury brand (since 1977) and King Koil, as the current market leader of luxury brand (since 1996) that already set up their foot in Indonesian market more than decades before.

The current market leader in Indonesian mattress held by Kingkoil as this claimed by the buyer of high end department stores such as Sogo, Seibu, Lafayette, Metro, Central, Lotte, and the owner of biggest furniture or mattress stores in greater Jakarta area such as Chandra Karya, Danamas, Diana Eva, Subur, Handal, New Home Centre, that lead all of them to give the most strategic and largest display area for Kingkoil brand in their stores compare with Sealy that currently has 26 sales outlets, and focus their distribution channel mainly in the Greater Jakarta area.

The objective of this research is to identify Sealy brand personality, which can be used as a guideline for the company when they set up their marketing communication plan. Aaker (1996, p. 138), the most referred figure of brand concept, in order to emphasize the importance of brand personality, quoted 2 famous sayings from Scott Talgo, a brand strategist, "a brand that captures your mind gains behavior, a brand that captures your heart gains commitment" and from Bob Dron, Harley-Davidson dealer in California-USA, "what other brand name do you see tattooed in people?" implying that Harley Davidson brand goes deep into their customer's heart and gives them an opportunity to express who they are or who they want to be by using the brand. While, Carlson, Donovan, and Cumiskey (2009) concluded in their research that brand personality is strategically important for every company to build a good relationship with their targeted customers. It is essential for Sealy Indonesia to understand and know its brand personality in order for them to be able to communicate effectively with their targeted customers, that in the end, will turn them into loyal Sealy customers.

In terms of practical significance, there is so many research that determines the brand personality in a various product category but rare in mattress product category, only 1 journal 
article related to mattress brand personality's research that found by the researcher so far, the researcher hopes that this research will enrich the practical world by giving a description of brand personality in the mattress product category within the luxury segmentation of Indonesia. While in terms of academic significance, the research will examine theoretical knowledge and its application in the fields of brand personality. The scope of the research covers only on brand personality study of Sealy based on its brand drivers that are obtained from Sealy Indonesia and other public documents available in the internet.

\section{LITERATURE REVIEW}

The following section will discuss previous studies that have been published in journals and become references in this research. Jennifer $L$. Aaker's brand personality dimensions and David A. Aaker's brand personality drivers' concept are widely used in many previous studies to determine brand personality. For example, Lazareva (2016) in her research, used David Aaker's brand personality drivers and examining those with Jennifer Aaker's dimensions to determine and describe the brand personality of several mattress brands such as Tuft \& Needle, Casper, Eve, and Napsie in America. Mustamil, Chung, and Shoki (2014) also used the dimensions to determine brand personality of Nike sports shoes in Malaysia. Das, Prakash, and Khattri (2012) used the same dimensions when they measured the brand personality of the 3 cola brands, namely CocaCola, Pepsi, and Thumbs Up in India, and they also assert that brand personality is considered to be an important factor for the success of a brand in terms of preference and choice because the customers interact with brands as if they were people that in the end make the customers choose a brand similarly with how they choose friends or with whom they want to have a relationship. In addition to that, Geuens, Weijters, and Wulf (2009) state that brand personality measurement must consist of only big 5 human personality dimensions to respond criticisms of a brand personality measurement concept that embrace too many aspects while Carlson et al.(2009) conclude that brand personality is strategically important in creating a good relationship with the targeted consumers.

Sealy is a mattress brand in the luxury segmentation and Ranchold (2015) was investigating the meaning of luxury brands from a consumer perspective which in the end provides an insight of how consumers perceive, search and buy luxury products. While both of Sokhela (2015) and Romero and Gomez (2014) suggest the luxury brand marketer to identify the traits for both of its customers and potential customers that must be associated with their brand personality.

\section{Brand Personality}

Aaker (1996, p. 141) defined brand personality as a set of human characteristics that are associated with a brand. Other researchers, Sweeney and Brandon (2006) explained brand personality in a broader definition as a set of human personality traits that correspond to the interpersonal domain of human personality and are relevant to describe the brand as a relationship partner. If a brand was a human, $\mathrm{He}$ or she would carry human personalities such as honest or dishonest, trendy or old-fashion, hardworking or lazybones, masculine or feminine, and so forth.

Kapferer and Azoulay (2003) found that consumers have no difficulty answering metaphorical questions such as: 'suppose the brand is a person, what kind of person would he/she be, with what personality?' In fact, the consumers are able to perceive the brands as having personality traits. He further explained that a brand constructs its character by communicating its personality to the consumers, which in turn clarifies what kind of person a brand would be if it was a human being. Aaker (1996) added that brand personality, like human personality, is both distinctive and enduring.

Finally, Aaker (1996, p. 150) elaborate 4 reasons why the marketers should use brand personality when they set up their marketing communication 
plan. Brand personality study can help the marketers by enriching their understanding of the customers' perception and attitude toward the brand, contributing to differentiate the brand identity among others, guiding the communication effort with the same and consistent message, and finally creating brand equity. As such, brand personality provides a powerful tool to develop an identity, a communication effort, and in fact, a whole marketing program (Aaker, 1996, p. 174).

\section{Brand Personality Dimensions}

Aaker (1997), marketing professor at Stanford Graduate School of Business and David Aaker's daughter, constructed a framework for describing and measuring brand personality through 5 core dimensions which consist of 15 facets that are further elaborated by 42 traits. This framework has been considered valid by many scholars and is frequently used to examine the personality of a brand by other researchers.

\section{How A Brand Personality is Identified}

Aaker (1996, p. 145-147) stated that a brand personality is affected by everything associated with the brand, the same as the perceived personality of a person is affected by everything associated with that person including his or her neighborhood, friends, activities, clothes, and manner of interacting. He further outlined
2 groups of characteristics that affecting perceptions of a brand personality, both related and unrelated to the product, that he called brand personality drivers, or simply drivers.

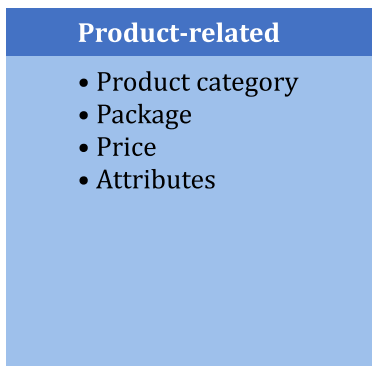

Non product-related
- User Imagery
- Sponsorships
- Symbols
- Age
- Advertising style
- Country of origin
- Company image
- CEO
- Celebrity endorsers

Figure 3. Brand personality drivers (adapted from Aaker, 1996, p. 146)

Product-related drivers can be primary drivers of brand personality. A bank or insurance company, from the product category point of view, will tend to assume a stereotypical "banker" personality such as competent, serious, masculine, older, and upper-class while an athletic shoe such as Nike or Reebok might tend to be rugged, outdoorsy, and adventures, as well as young and lively (Aaker,1996, p.145). A package, product attributes, and price will also influence brand personality, for example, the white box with black splotches, reminiscent of Holstein cows, provide a down-to-earth personality for Gateway Computer, and Weight Watchers that has "light" brand is described as being slender and athletic, while Tiffany as a luxury brand with high price

\begin{tabular}{|c|c|c|c|c|}
\hline \multicolumn{5}{|c|}{ Brand Personality Dimensions, Facets, and Traits } \\
\hline Sincerity & Sincerity & Sincerity & Sincerity & Sincerity \\
\hline $\begin{array}{l}\text { Down to earth } \\
\text { - Down to earth } \\
\text { - Family oriented } \\
\text { - Small town }\end{array}$ & $\begin{array}{l}\text { Daring } \\
\text { - Daring } \\
\text { - Trendy } \\
\text {-Exciting }\end{array}$ & $\begin{array}{l}\text { Reliable } \\
\text { - Reliable } \\
\text { - Hard working } \\
\text { - Secure }\end{array}$ & $\begin{array}{l}\text { Upper class } \\
\text { - Upper class } \\
\text { - Glamorous } \\
\text { - Good Looking }\end{array}$ & $\begin{array}{l}\text { Outdoorsy } \\
\text { - Outdoorsy } \\
\text { - Masculine } \\
\text { - Western }\end{array}$ \\
\hline $\begin{array}{l}\text { Honest } \\
\text { - Honest } \\
\text { - Sincere } \\
\text { - Real }\end{array}$ & $\begin{array}{l}\text { Spirited } \\
\text { - Spirited } \\
\text { - Cool } \\
\text { - Young }\end{array}$ & $\begin{array}{l}\text { Intelligent } \\
\text { - Intelligent } \\
\text { - Technical } \\
\text { - Corporate }\end{array}$ & $\begin{array}{l}\text { Charming } \\
\text { - Charming } \\
\text { - Feminine } \\
\text { - Smooth }\end{array}$ & $\begin{array}{l}\text { Tough } \\
\text { - Tough } \\
\text { - Rugged }\end{array}$ \\
\hline $\begin{array}{l}\text { Wholesome } \\
\text { - Wholesome } \\
\text { - Original }\end{array}$ & $\begin{array}{l}\text { Imaginative } \\
\text { - Imaginative } \\
\text { - Unique }\end{array}$ & $\begin{array}{l}\text { Successful } \\
\text { - Successful } \\
\text { - Leader }\end{array}$ & & \\
\hline $\begin{array}{l}\text { Cheerful } \\
\text { - Cheerful } \\
\text { - Sentimental } \\
\text { - Friendly }\end{array}$ & $\begin{array}{l}\text { Up-to-date } \\
\text { - Up-to-date } \\
\text { - Independent } \\
\text { - Contemporary }\end{array}$ & & & \\
\hline
\end{tabular}

Figure 2. Aaker's brand personality framework 
might be considered as wealthy, stylish, and perhaps a bit snobbish (Aaker,1996, p.146).

While product-related drivers clearly influence brand personality, non-product-related drivers also affect brand personality, include things like advertising style, country of origin, company image, CEO identification, and celebrity endorsers. For example, Calvin Klein's Obsession advertising help define a strong personality for the brand or a German brand like Audi might capture some perceived characteristics of German people such as precise, serious, and hard working. While user imagery, the image that comes from people that we see are using the brand or models that are hired to use the product in the advertising, for example, is showed by the upscale of Mercedes Bens car, or the sexy, sophisticated users personality of Calvin Klein (Aaker,1996, p.146-148). Other drivers such as sponsorship, symbol, and age also affect the brand personality as well.

So, we can identify and describe personality of certain brand by examining its drivers to find out what is the core values of each driver, and then, analyze it to find what personality traits suit those core values. Lazareva (2016) in her theses research to describe several mattresses brand personalities, through the observation of its drivers, for example, she concludes that the main personality of Tuft and Needle brand as honesty from sincerity dimension. If Tuft and Needle were a person, he or she would appear as someone who listens with empathy to every complaint and shares a similar disrespect to sales tricks and too high mattress price. The honesty personality is clearly stated from the quote of its founders, JT Marino and Daehee Park, saying that prices for mattresses were too high and were not necessarily justified by the quality of the product and followed by their clear positioning to advocate transparency in the business. Park further stated that he wants Tuft and Needle is known as an honest company that opens up the transparency of this industry. That kind of message such as price transparency, mattress stores are greedy, the same price for everyone all year round, or discount is the same with manipulation are consistently aired through their social media, prints, billboards, and tv advertising, as their marketing communication strategy to make the message clear and easy to understand by their customers (Lazareva, 2016, p. 45-51).

While for Casper, another mattress brand, she mentioned about the uniqueness of the brand name that has association with cute character, a friendly ghost, well-known by everyone since childhood, and also the simple white minimalist design for the mattress itself from the surface, border, logo tag on side, stylish white-blue box packaging, welcome kit, and safety blade for opening the vacuum package, hand-written thank you note from the Casper team, and a book of fairy tales tucked into the box. All of those things plus their marketing communication strategy focusing the message of their mattress is suitable for everyone with the series of eye-catching, hand-drawn ads feature a variety of characters from humans to animals to fictionary creatures, presented in a fun, humorous, and unexpected way to form the main personality of Casper as imaginative from excitement dimension (Lazareva, 2016, p. 53-58).

The same way analysis she uses to describe the main personality of Napsie brand as exciting by having at least 3 stand-out facets of daring in terms of product design, imaginative by creating its magic world of sleep and dreams, up to date with current industry trends and customer demands. Napsie is clearly seen to have a connection with excitement dimension by always using young people, not famous model but ordinary-looking people in their daily routine of waking up in the morning, having breakfast in bed, relaxing, doing some activities in bed such as reading, watching, and certainly looking fresh, healthy, happy, and energetic in their marketing communication strategy (Lazareva, 2016, p. 6673).

\section{The Luxury Mattress Segmentation}

There are at least 4 criteria to define the luxury 
mattress segmentation used in this research (Heine, 2012).

1. The brand came or originally from the countries traditionally known as the reference for luxury brands or high technology-perceived countries such as USA, England, Germany, Italy, and French.

2. The brand exists and has a good international reputation not only in Indonesia but also in many other developed and wealthy countries.

3. The brand is acknowledged as a premium brand by leading worldwide organizations relevant to the mattress product categories such as International Sleep Product Association, European Bedding Industries' Association, or Furniture Today.

4. Have at least one model with a premium retail price. The price will be categorized premium if the mattress retail price reaches more than IDR. 20 million per 1 mattress for the double size or size of 2 adult users.

\section{RESEARCH METHOD}

In this research, the researchers choose qualitative research method with pragmatist paradigm. The method will give a deep perspective and a comprehensive understanding of a given phenomenon within a particular context in the final result, while the paradigms will give freedom of choice to the researchers to choose methods, techniques, and procedures that best meet the needs and purposes of the research (Creswell, J.W., 2007).
Again, the identification of Sealy brand personality will be obtained by examining 13 unit analysis from Sealy's brand personality drivers, both product-related and non product-related, to know what are the core values of each driver (Aaker, 1996, p. 145). In fact, this research uses the same analytical techniques as those carried out by previous researcher, Svetlana Lazareva, when she analyzed the personality of several mattress brands namely Tuft and Needle, Casper, and Napsie in 2016. As the personality of Sealy should be the same everywhere in the world, then the drivers of Sealy can be taken either from Sealy Indonesia or other Sealy subsidiaries such as Malaysia and Singapore as the closest countries with Indonesia or even from Australia and USA as the parent companies and share holder of Sealy Indonesia. Furthermore, the finding core values of each driver will be analyzed by matching and conforming it to 42 traits and 5 dimensions of Aaker's brand personality framework. What personality traits suit Sealy drivers, and how many traits appear in the end, will define the strongest personality and its dimension.

\section{RESULT AND DISCUSSION}

As described in the methodology section, the first step in identifying brand personality from Seally is to study 13 units of analysis based on its drivers. The following are the result from examining of 13 Sealy brand personality drivers.

Sealy Brand
Personality Drivers
- Product-related drivers
1. Product category
2. Package
3. Price
4. Attributes
- Non Product-related drivers
5. User imagery
6. Sponsorships
7. Symbols
8. Age
9. Advertising style
10. Country of origin
11. Company image
12. CEO
13. Celebrity enodrsers

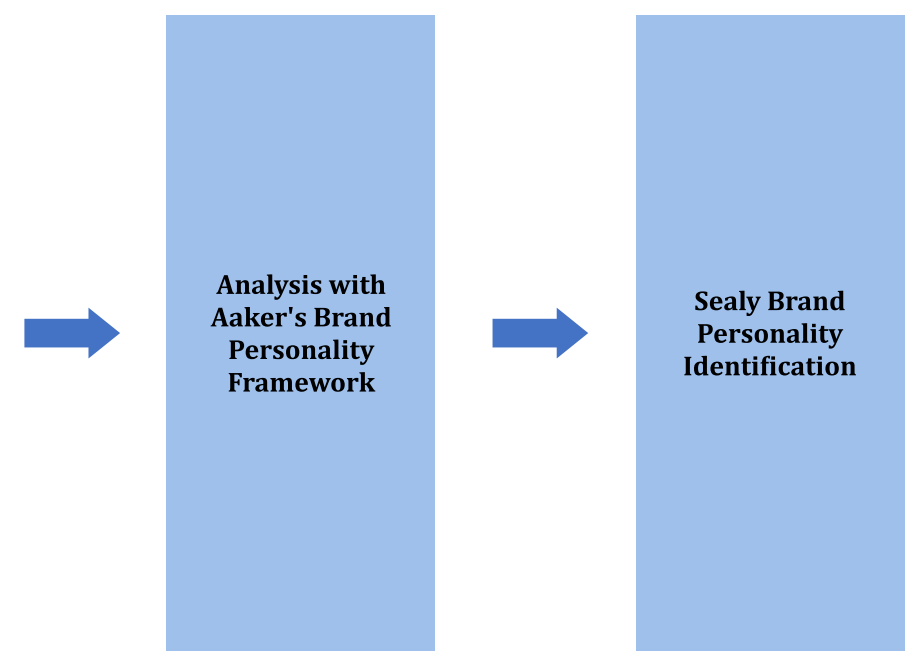

Figure 4. Category Construction 


\section{Brand Personality Drivers Product category}

Luxury mattress which has association with images in the minds of consumers that comprise associations about a high level of price, quality, aesthetics, rarity, extraordinariness, and a high degree of non-functional associations (Heine, 2012)

\section{Package}

- Fully imported mattresses

- 10 years new-unit replacement guarantee

- Sealy global quality concept means Sealy mattresses that are sold in Indonesia have the same quality with Sealy mattresses that are sold anywhere in the world

\section{Price}

The price range of more than Rp. 20 million per 1 pcs of double size mattress which will be considered very expensive or unaffordable for most common mattress buyers in Indonesia

- Posturepedic Palatial Crest: (Rp. 53 million Rp. 80 million)

- $\quad$ Posturepedic Enhance: (Rp. 22 million - Rp. 45 million)

\section{Attributes}

- Sealy logo is a butterfly like-form with Sealy italic word in the middle, and blue and white as its main color. In mattress industry, blue color associated with peace and calmness, while white color with cleanliness and purity (Lazareva, 2016)

- Sealy tagline is "Support You Trust Comfort You'll Love"

- 'Sealy' is the primary brand - it's the name of the company, it's the butterfly logo that appears on every product and it's the name that every consumer knows

- 'Posturepedic' is the sub brand - it's the name used as the name of the highest or top product range of Sealy mattresses and has a meaning as "the mattress that provides its users orthopaedically correct support, pressure-relieving comfort, and long-lasting durability functions" ("What is Sealy Posturepedic," n.d.).

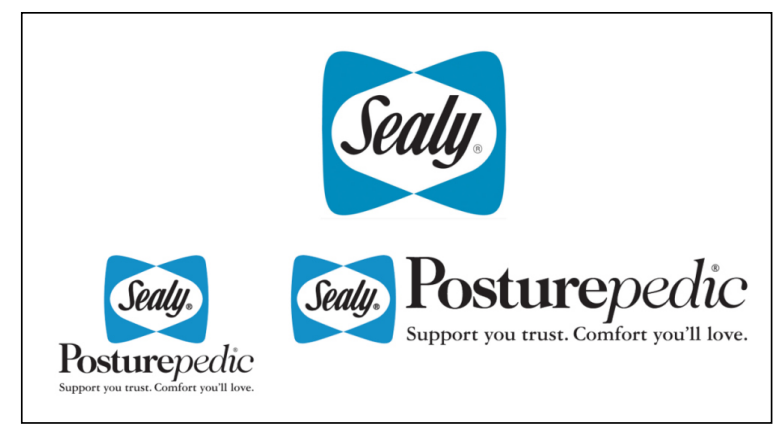

Figure 6. Sealy attributes (logo and tagline)

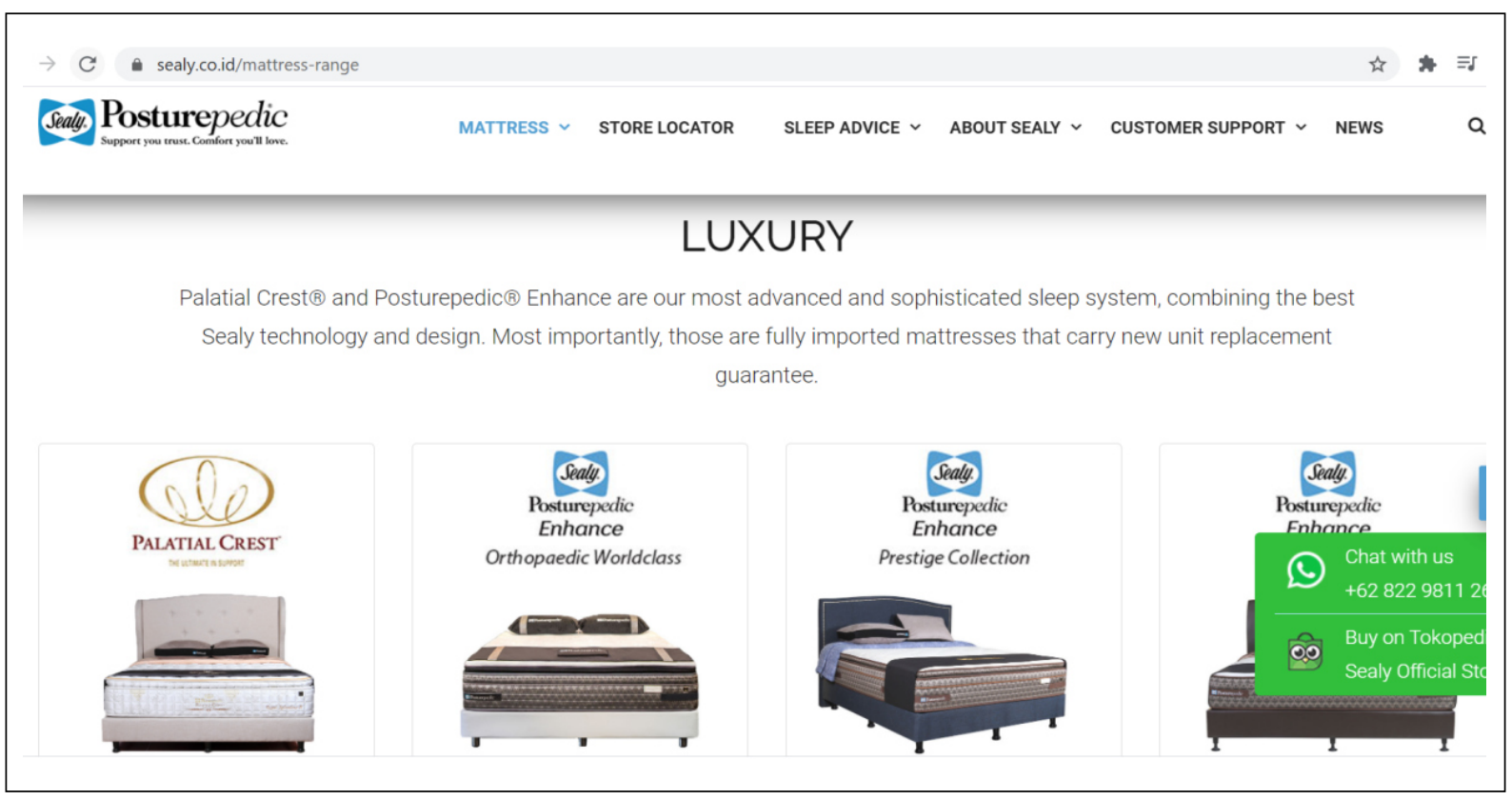

Figure 5. Sealy package 


\section{User imagery}

Sealy mostly uses a successful, healthy, active, and middle age-mature woman figure as their models on their ads or catalogs, sometimes they also use man and children figure when they want to portray a happy-healthy family.

\section{Sponsorships}

- Sealy Singapore has once became a sponsor for a fundraising campaign organized by
National Arthritis Foundation and continue to keep cooperating with Ronald McDonald House Charities Singapore until now ("Sealy Singapore extends support to Ronald McDonald House Charities," 2019, 2 April).

- Sealy Australia continues to keep cooperating with Ronald McDonald House Charities Australia, Queensland Ballet, and Soft Landing for mattress recycling ("Our promise to Australia and you," n.d.)

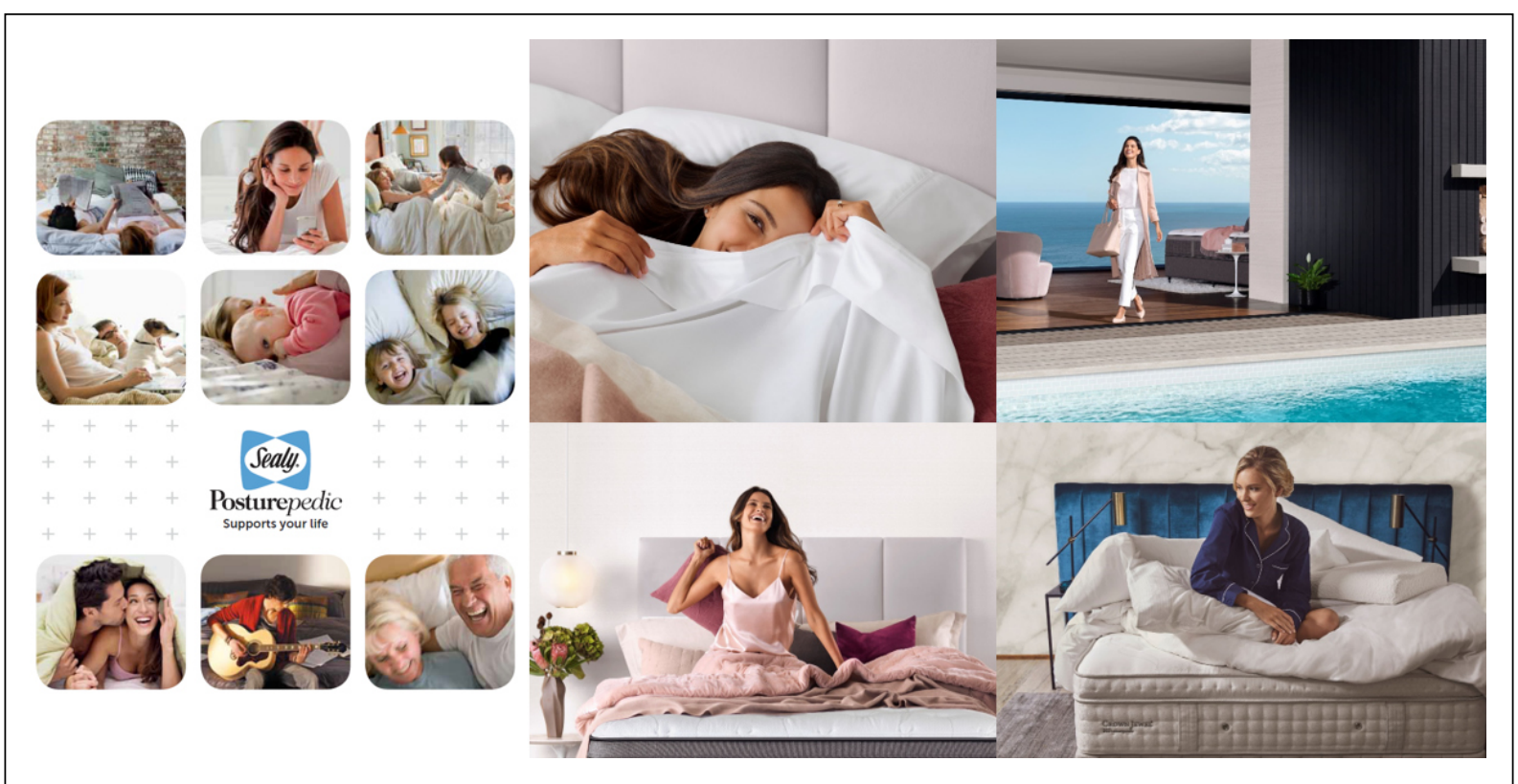

Figure 7. Sealy user imagery

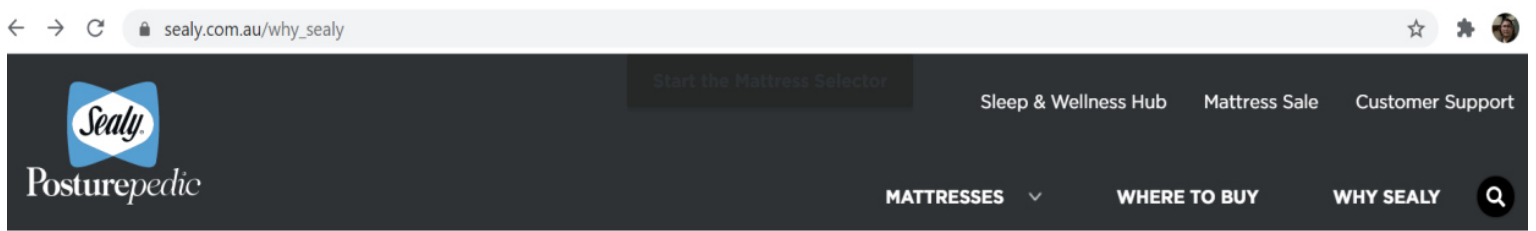

OUR PROMISE TO AUSTRALIAAND YOU

We will not compromise in our pursuit to build environmentally friendly beds that support all Australians

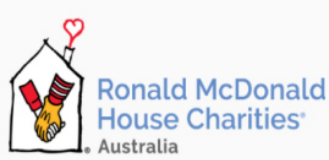

NATIONAL PARTNER

Helping Australian families in their time of need

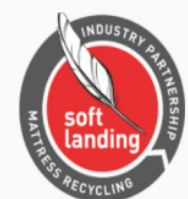

FOUNDING MEMBER

Working towards a better environment.

Figure 8. Sealy sponsorships

\section{Queensland Ballet}

CORPORATE PARTNER

Supporting dancers now and in the future. 


\section{Symbols}

- Perpetual Endorsement from Orthopaedic Advisory Board that is always advertised in almost every printed advertising to send a message that the product created through technical consultation with the expert of human anatomy

- Titanium as the material of its spring system, it is patented and used in every product catalog to give association from the traits of titanium which is stronger and lighter.

\section{Age}

- Though Sealy entered Indonesia market quite late compare to other brands, but in terms of the establishment year in their respective country origin, Sealy which was established in 1881, in fact, is the 2nd oldest brand after Simmons which was established in 1870 ("Our Company," n.d.)

\section{Advertising style}

- The advertising communication theme that mostly used by Sealy:

- The fresh, smile, and happy-look models that are doing activities such as waking up, reading, watching, or just relaxing on Sealy beds.

- The fresh, smile, and happy-look models that are doing activities after having a good and restful night's sleep.

- The superiority of Sealy beds compared to other beds, especially in terms of technology

- The achievement of Sealy such as the awards or title that have been given from respectable-relevant organization such as the world's \#1 USA bedding producer (Perry, 2020, June 8), the best mattress of Expat Living Reader's Choice award for 3 years in a row 2018, 2019, 2020 in Singapore ("Readers' Choice Awards results are in," 2020, January 10), and Canstar Blue "Most Satisfied Customer Award" for mattress brand in Australia ("Why Sealy Posturepedic," n.d.) etc.

- The wealthy image described by a Sealy bed is often shown by glamorous-image models, usually woman, in the luxury indoor location such as a room with very expensive interior or a magnificent theater room, and also beautiful natural outdoor locations in the garden, beach, etc

- The story telling of relevant information with Sealy from trusted sources such as famous artists, engineers, architect, doctors, orthopaedic practicioners, iconic international hotels representatives.

\section{Country of origin}

Though Sealy has global quality concept that emphasize each Sealy mattress sold anywhere has the same global quality standard, all Sealy subsidiaries have to mention in their websites or other advertising tools that Sealy is originated

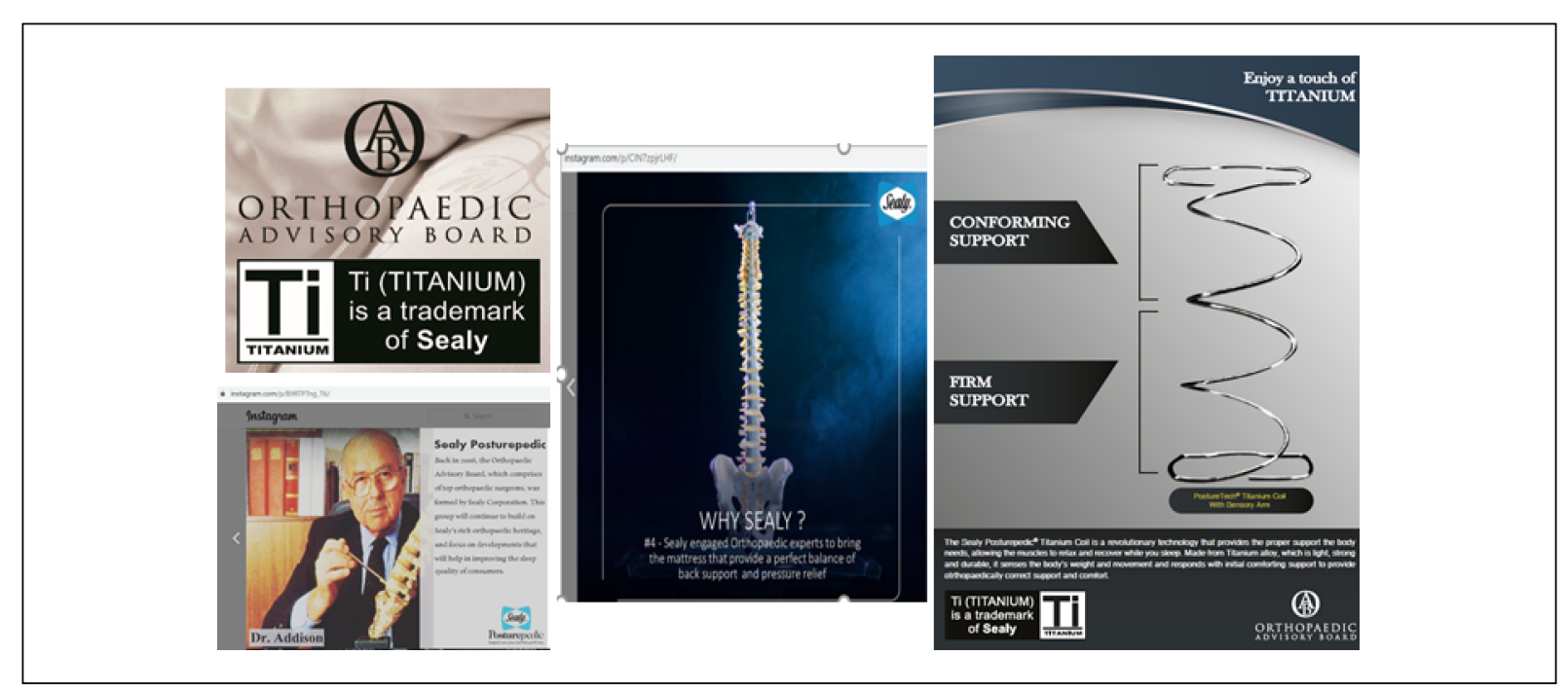

Figure 9. Sealy symbols 


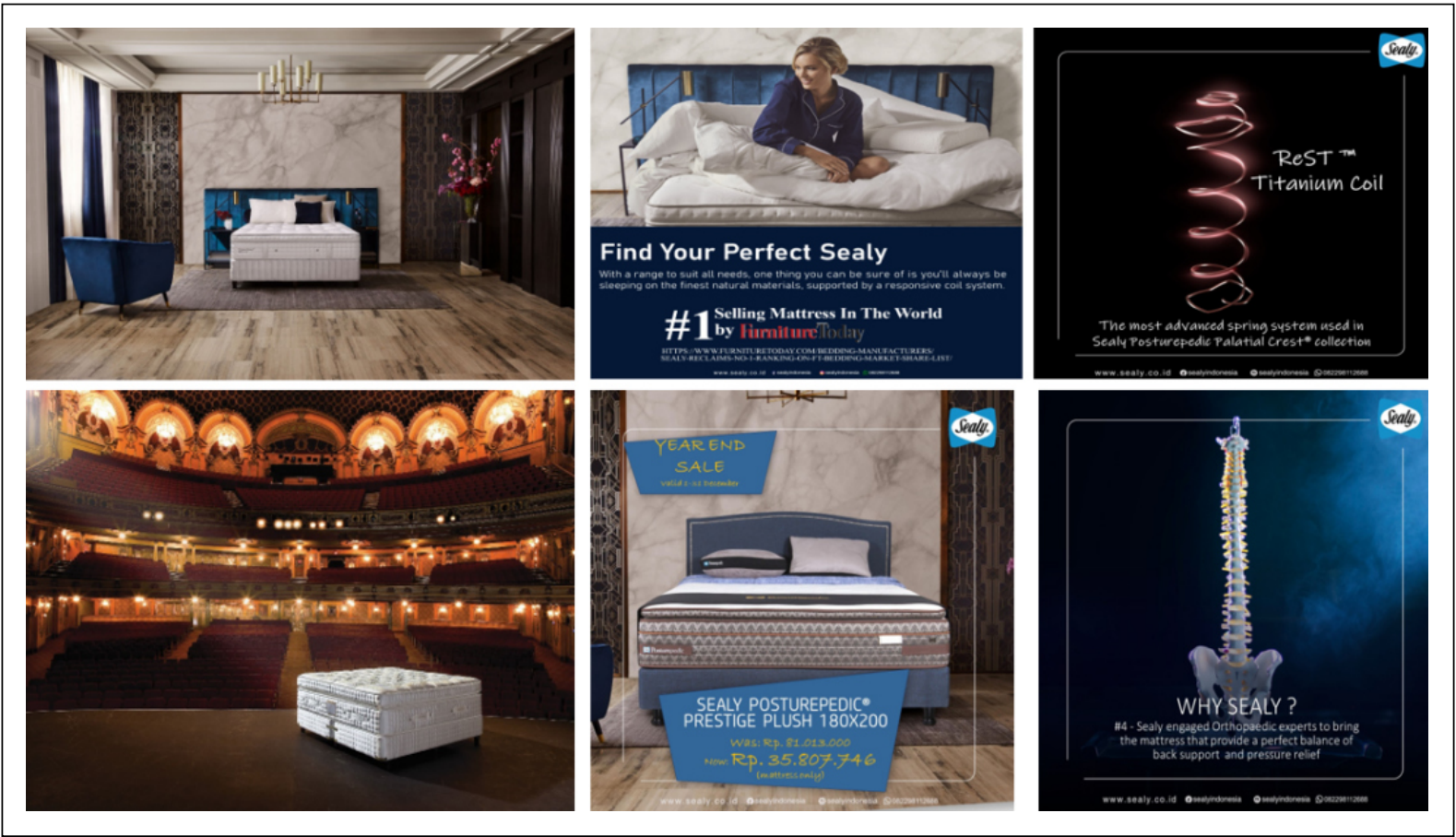

Figure 10. Sealy advertising style

from USA (“Our Company," n.d.).

\section{Company image}

Sealy Indonesia is a subsidiary from Sealy Australia, the biggest premium mattress manufacturer in Australia, and TempurSealypedic USA, a public listed company that sells Sealy and Tempur brand, and currently are considered as the 2nd biggest bedding producers in the world after Simmons-Serta holding company ("Our Company," n.d.).

\section{CEO}

CEO of Sealy Indonesia, who is also the CEO of Sealy Singapore, together with CEO of Sealy Australia and USA always remind all Sealy staff about the Sealy global product proposition as unique, superior, and proprietary ("Our Company," n.d.). Detail explanation about those product proposition are as below:

- Unique: Sealy mattresses have unique support systems, spring system, and edge support technology, that are not used by any other brands. Simply, Sealy uses a different technology that no other brands use.

- Superior: Sealy summarize their superiority on mattress support system by informing the unique-patented spring system based on its construction and titanium-added material, and edge support system based on its construction and polyethylene material which both are used by Sealy. Simply, Sealy's technology is better in terms of the construction, the materials, and most importantly, can be proved scientifically.

- Proprietary: the unique and superior technology such as SRx, and ReST spring systems, Titanium alloy as compound material of the spring, and Unicased edge support system are patented by Sealy. Simply, Sealy has legal rights to claim they are the owner of those technologies due to long internal research from their $R \& D$ development.

\section{Celebrity endorsers}

Sealy is not aggressively using global figure to endorse its brand but give freedom to its subsidiary in each country to decide:

- in Malaysia, Sealy once collaborated with Benjamin Young, founder and group CEO of the Big group, a successful culinary young businessman in the country, to become a temporary brand ambassador and promote 
one of Sealy luxury mattress collection there ("Ask Benjamin Young, why Sealy mattress is so good," 2017, July 21).

- In Australia, Sealy engage with Alice Parkinson, an Australian artist known for X-Men Origins: Wolverine (2009), Sanctum (2011), and Where the Wild Things Are (2009) as their TV commercial ads artist

- While in Indonesia, Sealy collaborates with young and quite famous artists such as
Melaney Ricardo, Rasyena Hikmayudhi, and Rigen Rakelna to promote Sealy in Indonesia through a few postings in their respective Instagram accounts.

This section will analyze all the finding core values of Sealy brand personality drivers obtained from the previous chapter by matching and conforming it with Aaker's personality traits, and the result as below:

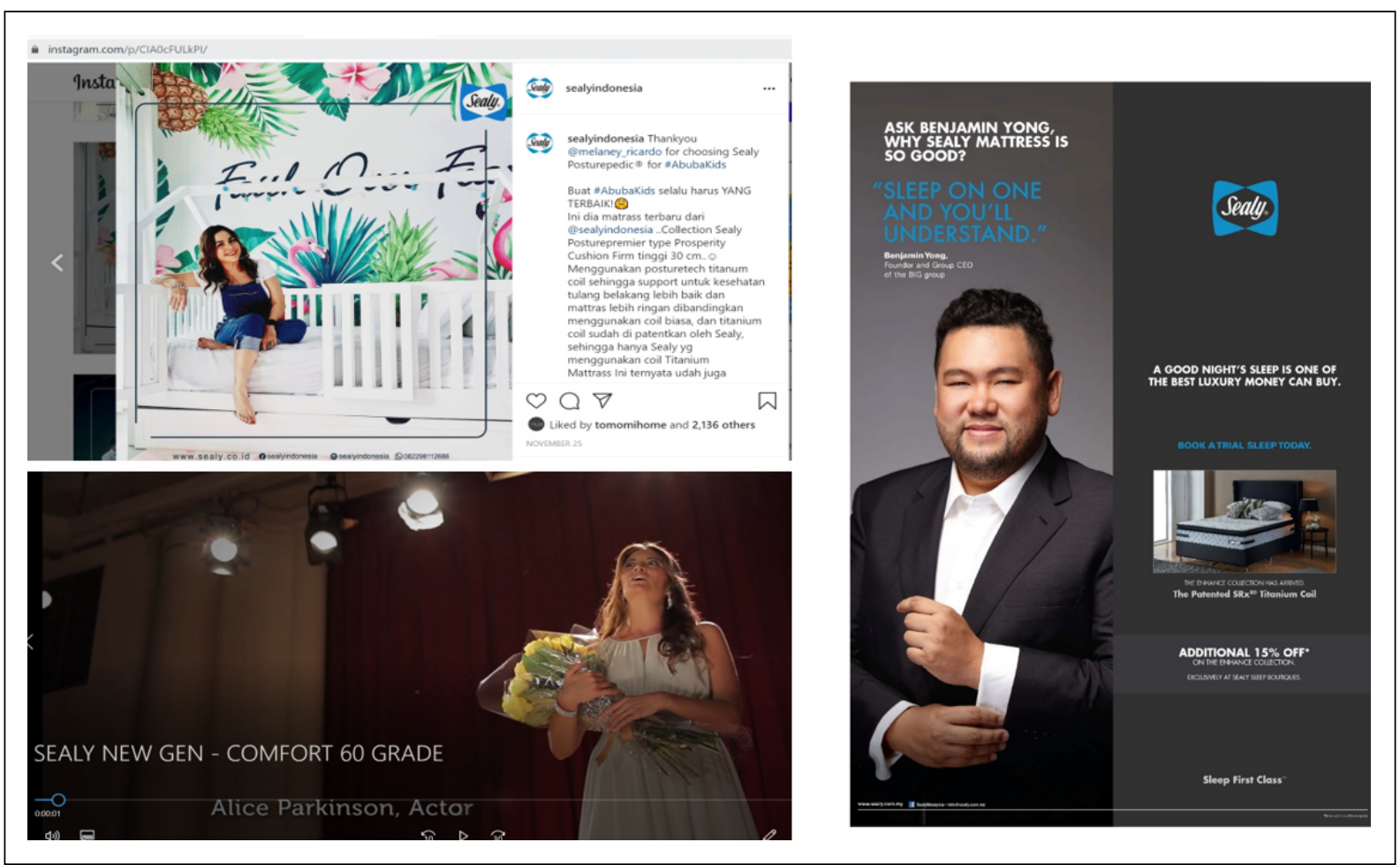

Figure 11. Sealy celebrity endorsers

Table 1. Sealy-drivers analysis with Aaker's brand personality framework

\begin{tabular}{|c|c|c|}
\hline Unit Analysis & Core Values & Suitable Personality Traits \\
\hline 1. & $\begin{array}{l}\text { Luxury mattress which has association with images in the minds of consumers } \\
\text { that comprise associations about a high level of price, quality, aesthetics, rarity, } \\
\text { extraordinariness and a high degree of non-functional associations (Heine, 2012) }\end{array}$ & $\begin{array}{l}\text { Upper class, Glamorous, } \\
\text { Good Looking, Reliable, } \\
\text { Secure, Intelligent, Technical }\end{array}$ \\
\hline 2. & $\begin{array}{l}\text { - Fully imported mattresses } \\
\text { - } 10 \text { years new-unit replacement guarantee } \\
\text { Sealy global quality concept means Sealy mattresses that are sold in } \\
\text { Indonesia have the same quality with Sealy mattresses that are sold everywhere } \\
\text { in the world }\end{array}$ & $\begin{array}{l}\text { - Upper class } \\
\text { - Secure } \\
\text { - Reliable }\end{array}$ \\
\hline 3. & $\begin{array}{l}\text { The price range of more than Rp. } 20 \text { million per } 1 \text { pcs of double size mattress } \\
\text { which will be considered very expensive or unaffordable for most common } \\
\text { mattress buyers in Indonesia } \\
\text { - Palatial Crest collection : Rp. } 52 \text { - Rp. } 45 \text { million - Rp. } 80 \text { million) } \\
\text { Posturepedic Enhance : Rp. } 22 \text { million - Rp. } 45 \text { million) }\end{array}$ & Upper Class \\
\hline 4. & $\begin{array}{l}\text { - Sealy logo is butterfly like-form with Sealy italic word in the middle, and blue } \\
\text { and white as its main color. In sleep industry, blue color is associated with peace } \\
\text { and calmness, while white color with cleanliness and purity (Lazareva, 2016) } \\
\text { - Sealy tagline is "support you trust comfort you'll love" }\end{array}$ & - Smooth \\
\hline
\end{tabular}


- 'Sealy' is the primary brand - it's the name of the company, it's the butterfly logo that appears on every product and it's the name that every consumer knows

- 'Posturepedic' is the sub brand - it's the name used as the name of the highest or top product range of Sealy mattresses and has a meaning as "the mattress that provides its users orthopaedically correct support, pressure-relieving comfort, and long-lasting durability functions" ("What is Sealy Posturepedic," n.d.)

5. Sealy mostly uses successful, healthy, active, and middle age-mature woman figure as their models on their ads or catalogs though sometimes they occasionally use man and children figure when they want to portray a happy-healthy family.

6. - Sealy Singapore has once became a sponsor for a fundraising campaign organized by National Arthritis Foundation and continue to keep cooperating with Ronald McDonald House Charities Singapore until now ("Sealy Singapore extends support to Ronald McDonald House Charities," 2019, 2 April)

- Cooperating with Ronald McDonald House Charities Australia, Queensland Ballet, and Soft Landing for mattress recycling ((“Our promise to Australia and you," n.d.))

7. - Perpetual Endorsement from Orthopaedic Advisory Board that is always advertised in almost every printed advertising to send a message that the product created through technical consultation with the expert of human anatomy

- Titanium as the material of its spring system, even patented, is used in every product catalog to give association from the traits of titanium, stronger and lighter, which is a very positive attributes for the materials

8. - Though Sealy entered Indonesia market quite late compare to other brands, but in terms of the establishment year in their respective country origin, Sealy which was established on 1881, in fact, is the 2nd oldest brand, only Simmon was established earlier than Sealy, 1870 ("Our Company," n.d.).

9. The advertising theme that mostly used by Sealy are always described by:

- The fresh, smile, and happy-look models that are doing activities such as waking up, reading, watching, or just relaxing on Sealy beds

- The fresh, smile, and happy-look models that are doing activities after having a good and restful night's sleep

- The superiority of Sealy beds compared to other beds, especially in terms of technology

- The achievement of Sealy such as awards or title that is given from respectable-relevant organization such as the world's \#1 USA bedding producer (Perry, 2020, June 8), the best mattress of Expat Living Reader's Choice award for 3 year in a row 2018, 2019, 2020 in Singapore ("Readers' Choice Awards results are in," 2020, January 10), and Canstar Blue "Most Satisfied Customer Award" for mattress brand in Australia ("Matress Awards," n.d.), etc

- The wealthy image that is decribed by a Sealy bed sometimes completed by glamorous-image models, usually woman, in the luxury indoor location such as a room with very expensive interior or a magnificent theater room, and also beautiful natural outdoor locations in the garden, beach, etc

- The story telling of relevant information with Sealy from trusted sources such as famous artists, engineers, architect, doctors, orthopaedic practicioners, iconic international hotels representatives

10. Though Sealy has global quality concept that emphasize every Sealy mattress sold anywhere has the same global quality standard but all Sealy subsidiaries have to mention in their websites or other advertising tools that Sealy is originated from USA

11. Sealy Indonesia is a subsidiary from Sealy Australia, the biggest premium mattress manufacturer in Australia, and Tempur-Sealypedic USA, a public listed company that sells Sealy and Tempur brand, and currently are considered as the 2 nd biggest bedding producers in the world after Simmons-Serta holding company

12. CEO of Sealy Indonesia, who also is held by the CEO of Sealy Singapore, together with CEO of Sealy Australia and USA always remind all Sealy staff about Sealy global product proposition as:

- Unique: Sealy mattresses has unique support systems, spring system and edge support technology, that are not used by any other brands. Simply, Sealy uses different technology that no other brands use

- Superior: Sealy summarize their superiority on mattress support system by informing the unique-patented spring system based on its construction and titanium-added material, and edge support system based on its construction and polyethylene material which both are used by Sealy. Simply, Sealy's technology is better in terms of the construction, the materials, and most importantly, can be proved scientifically.
- Corporate

- Technical

Feminine, Charming, Family Oriented, Upper Class

- Technical and Successful

- (Successful), Leader and Corporate

- Intelligent and Technical

- (Technical) and Leader

Leader and Successful

- Feminine, Charming

and Cheerful

- (Charming) and Confident

- Leader

- (Leader) and successful

- Glamorous and Upper Class

- Reliable

Leader, Successful,

Upper Class

Corporate, Leader,

and Successful

- Unique and Technical

- Leader 
- Proprietary: all of those unique and superior technology are patented by Sealy such as SRx, and ReST spring systems, Titanium alloy as compound material of the spring, and Unicased edge support system. Simply, Sealy has legal rights to claim they are the owner of those technologies due to long internal research from their R\&D development

13. Sealy is not aggressively using global figure to endorse its brand but give freedom to its subsidiary in each country to decide:

- In Malaysia, Sealy once collaborated with Benjamin Young, founder and group CEO of the Big group, successful culinary young businessman in the country, to become temporary brand ambassador and promote one of Sealy luxury mattress collection there ("Ask Benjamin Young, why Sealy mattress is so good," 2017, July 21)

- In Australia, Sealy engage with Alice Parkinson, an Australian artist known for X-Men Origins: Wolverine (2009), Sanctum (2011), and Where the Wild Things Are (2009) as their TV commercial ads artist

- While in Indonesia, Sealy collaborates with young and quite famous artists such as @melaneyricardo, @rasyenahikmayudhi, and @rigensih to promote Sealy in Indonesia through a few postings in their respective Instagram accounts ("Thankyou @melaney_ricardo for choosing Sealy Posturepedic $®$ for \#AbubaKids," 2020, November 25)
- Corporate, Reliable, and Secure

- Successful,

Upper Class, Young

- (Successful, Upper Class), feminine, charming

- (Successful and Young)

\section{Sealy brand personality identification}

The suitable personality traits generated from those 13 unit analysis are collected, grouped, and recorded according to their facets to form the brand personality dimension. In the grouping process, each unit analysis can only generate 1 same personality trait, so if there are more than 1 same personality trait appear on certain same unit analysis then only 1 trait is recorded into the table recapitulation. For example, in the unit analysis \#13, Celebrity Endorser, personality traits of "successful" appear ( $3 \mathrm{x}$ ) and "young" (2x), but because all of those traits are came from the same unit analysis then successful and young traits will be recorded only once (1x) in the table.

Table 2. Sealy personalities identification

\begin{tabular}{|c|c|c|c|c|}
\hline No & $\begin{array}{l}\text { Personality } \\
\text { Traits }\end{array}$ & $\begin{array}{l}\text { Number } \\
\text { of Traits }\end{array}$ & $\begin{array}{l}\text { Number of } \\
\text { Traits } / 13\end{array}$ & $\begin{array}{l}13 \text { Sealy } \\
\text { Brand Personality Drivers }\end{array}$ \\
\hline 1 & Leader & 7 & $54 \%$ & $\begin{array}{l}\text { Sponsorships, Symbols, Age, Advertising style, Company image, } \\
\text { Country of origin, CEO }\end{array}$ \\
\hline 2 & Upper Class & 7 & $54 \%$ & $\begin{array}{l}\text { Product category, Package, Upper class, User Imagery, Advertising } \\
\text { style, Country of origin, celebrity endorsers }\end{array}$ \\
\hline 3 & Successful & 6 & $46 \%$ & $\begin{array}{l}\text { Sponsorships, Age, Advertising style, Company Image, Country } \\
\text { of origin, Celebrity endorsers }\end{array}$ \\
\hline 4 & Technical & 5 & $38 \%$ & Product category, Attributes, Sponsorships, Symbols, CEO \\
\hline 5 & Corporate & 4 & $31 \%$ & Attributes, Sponsorships, Company Image, CEO \\
\hline 6 & Reliable & 4 & $31 \%$ & Product category, Package, Advertising style, CEO \\
\hline 7 & Secure & 3 & $23 \%$ & Product category, Package, CEO \\
\hline 8 & Intelligent & 3 & $23 \%$ & Product category, Attributes, Symbols \\
\hline 9 & Charming & 3 & $23 \%$ & User imagery, Advertising style, Celebrity endorsers \\
\hline 10 & Feminine & 3 & $23 \%$ & User imagery, Advertising style, Celebrity endorsers \\
\hline 11 & Glamorous & 2 & $15 \%$ & Product category, Advertising style \\
\hline 12 & Good Looking & 1 & $8 \%$ & Product category \\
\hline 13 & Smooth & 1 & $8 \%$ & Attributes \\
\hline 14 & Confident & 1 & $8 \%$ & Advertising style \\
\hline 15 & Unique & 1 & $8 \%$ & CEO \\
\hline 16 & Young & 1 & $8 \%$ & Celebrity endorsers \\
\hline 17 & Cheerful & 1 & $8 \%$ & Advertising style \\
\hline \multirow[t]{2}{*}{18} & Family Oriented & 1 & $8 \%$ & User Imagery \\
\hline & Total & 54 & & \\
\hline
\end{tabular}


Total 18 personality traits appear when the researchers analyze the core values of 13 Sealy brand personality drivers. Based on the table, we can describe the Sealy brand personality as below:

- There are 2 strongest or main Sealy personalities, leader and upper class, as both of those personalities appear in the 7 out of 13 drivers (54\%), or more than $1 / 2$ of total available drivers.

- $\quad$ After the 2 strongest personalities, there are 4 other quite strong Sealy personalities, successful (46\%), technical (38\%), corporate (31\%), reliable (31\%), as all of those personalities appear in at least 4 out of 13 drivers (30\%), or almost $1 / 3$ of total available drivers.

- Finally, there are 12 weak or very weak Sealy personalities, as all of those personalities appear in less than $1 / 3$ of total available drivers.

\section{Sealy brand personality dimension}

Total number of 54 personality traits appear when the researchers analyze the core values of 13 Sealy brand personality drivers with Aaker's brand personality framework which in the end form 4 dimensions. Based on the table, we can describe the Sealy brand personality dimensions as below:

- 4 dimensions out of a total 5 Aaker's dimension are formed from the appearing personality traits, but the strongest dimension is competence because there are
33 personality traits (61\%) support the dimension.

- $\quad$ The 2 nd strongest dimension is sophistication because there are 17 personality traits (31\%) support the dimension.

- Finally, the other 2 dimensions, excitement and sincerity, are very weak or can be considered irrelevant as both of them are supported by only 2 personality traits (4\%).

\section{CONCLUSION AND RECOMMENDATION}

The overall findings from the analysis concluded that Sealy has several personalities, total of 18 personalities, however, only 6 personalities can be considered quite strong which is successful, technical, corporate, reliable, with leader and upper class as Sealy main or strongest personalities. In terms of personality dimensions, there are 4 dimensions formed from the analysis, which is competence, sophistication, excitement, and sincerity, though the last 2 dimensions are too weak or can be considered irrelevant. In summary, we can say the Sealy personalities are leader and upper class from dimension competence and sophistication.

The result of this research again proved that Aaker's brand personality framework is useful and applicable, including in the mattress product category. The identification of Sealy personalities, leader and upper class, should become a guideline for the company and consistently being used as the focus of Sealy's marketing communication plan message in order for the company to

Table 3. Sealy personality dimensions identification

\begin{tabular}{|c|c|c|c|c|}
\hline No & $\begin{array}{l}\text { Personality } \\
\text { Dimension }\end{array}$ & $\begin{array}{c}\text { Number of } \\
\text { Traits/54 }\end{array}$ & $\begin{array}{l}\text { Number } \\
\text { of Traits }\end{array}$ & $\begin{array}{l}\text { Personality } \\
\text { Traits }\end{array}$ \\
\hline \multirow[t]{3}{*}{1} & Competence & $61 \%$ & 14 & Leader (7), successful (6), confident (1) \\
\hline & & & 12 & Technical (5), corporate(4), intelligent (3) \\
\hline & & & 7 & Reliable (4), secure (3) \\
\hline \multirow[t]{2}{*}{2} & Sophistication & $31 \%$ & 10 & Upper class (7), glamorous (2), good looking (1) \\
\hline & & & 7 & Charming (3), feminine (3), smooth (1) \\
\hline \multirow[t]{2}{*}{3} & Excitement & $4 \%$ & 1 & Young (1) \\
\hline & & & 1 & Unique (1) \\
\hline \multirow[t]{3}{*}{4} & Sincerity & $4 \%$ & 1 & Family Oriented (1) \\
\hline & & & 1 & Cheerful (1) \\
\hline & Total & $100 \%$ & 54 & \\
\hline
\end{tabular}


communicate effectively with their current and potential customers through winning their heart and loyalty.

The findings of this research could serve as a starting point for practical world to understand more about brand personality of mattress product category, especially in the luxury segmentation. The construct of this research could act as a reference in designing luxurious mattress product which would ultimately fit the desired personality of its targeted consumers. It is recommended that there is further research from the company on Sealy brand personality perception based on Sealy users and non-users, so the company can measure its marketing communication plan and evaluate what needs to be improved or changed and what needs to be maintained.

\section{REFERE N C E S}

Aaker, D.A. (1991). Managing Brand Equity. New York, United States of America: The Free Press.

Aaker, D.A. (1996). Building Strong Brand. New York, United States of America: The Free Press.

Aaker, J.L. (1997). Dimension of brand personality. Journal of Marketing Research, 34(3), $347-357$. Retrieved from https://www.gsb.stanford.edu/sites/gsb/files/publication-pdf/ Dimensions_of_Brand_Personality.pdf

Ask Benjamin Young, why Sealy mattress is so good. (2017, July 21). Facebook @Sealy Malaysia. Retrieved from https://www.facebook.com/page/279050927621/search?q=benjamin

Carlson, B.D., Donovan, D.T., \& Cumiskey, K.J. (2009). Consumer-brand relationships in sport: brand personality and identification. International Journal of Retail \& Distribution Management, 37(4), 370-384. DOI 10.1108/09590550910948592

Das J.K., Prakash O, and Khattri V (2012). Brand personality mapping: a study on Colas. Asian Journal of Management Research, 3(1), 193-200. Retrieved from https://www.researchgate.net/ publication/332728617_Brand_Personality_Mapping_A_study_on_Colas

Geuens, M., Weijters, B., \& Wulf, K.D. (2009). A new measure of brand personality. International Journal of Research in Marketing, 26(2), 97-107. DOI : https://doi.org/10.1016/j.ijresmar.2008.12.002

Grand View Research. (2019, July). Home Bedding Market Size, Share \& Trends Analysis Report By Type (Mattresses, Bed Linens, Pillows, Blankets), By Distribution Channel (Offline, Online), By Region, And Segment Forecasts, 2019 - 2025. Retrieved from https://www.grandviewresearch.com/ industry-analysis/home-bedding-market

Heine, K. (2012). The Concept of Luxury Brands. (2th Ed.). Berlin, Germany: Technische Universitat Berlin. Kapferer, J.N., \& Azoulay, A. (2003). Do brand personality scales really measure brand personality? Journal Brand Management, 11(2), 43-55. DOI: 10.1057/palgrave.bm.2540162 · Source: OAI

Ken Research. (2017, September 20). Indonesia Mattress Market is Expected to Cross USD 350 Million by 2021: Ken Research. Retrieved from https://www.prnewswire.com/news-releases/indonesiamattress-market-is-expected-to-cross-usd-350-million-by-2021-ken-research-646292073.html

Ken Research. (2017, September 21). Indonesia Mattress Market Future Outlook to 2021. Retrieved from https://www.kenresearch.com/blog/2017/09/indonesia-mattress-market-future-outlook-2021ken-research/

Lazareva, S. (2016). Creating a brand identity for a new mattress brand case: Napsie by Studio Moderna. (Master's theses, JAMK University of Applied Sciences, Jyvaskyla, Finland). Retrieved from https:/ /www.theseus.fi/handle/10024/121089

Matress Awards.(n.d.). Sealy Posturepedic. Retrieved from https://www.sealy.com.au/about-sealy/ mattress-awards 
Mustamil, N., Chung, H.Y., \& Shoki, M.B.M.A. (2014). Determining brand personality of Nike sports shoes using Aaker's brand personality scale. International Journal for Innovation Education and Research, 2(06), 128-137. Retrieved from https://www.semanticscholar.org/paper/DeterminingBrand-Personality-of-Nike-Sports-Shoes-Mustamil-Chung/ e896a9e359b6296a9e9caf0dab3100cd2d229385?p2df

Our company (n.d.) Sealy Posturepedic. Retrieved from https://www.sealy.co.id/our company

Our promise to Australia and you (n.d.) Sealy Posturepedic. Retrieved from https://www.sealy.com.au/ why_sealy

Perry, D. (2020, June 8). Sealy reclaims No. 1 rankings on FT bedding market share list. Furniture Today. Retrieved from https://www.furnituretoday.com/bedding-manufacturers/sealy-reclaims-no-1ranking-on-ft-bedding-market-share-list/

Readers' Choice Awards results are in. (2020, January 10). Facebook @Sealy Singapore. Retrieved from https://www.facebook.com/SealyAsiaSingapore/posts/10158783452461808

Romero, M.P.T., \& Gomez, M.M.O. (2014). Brand Personality and Purchase Intention. European Business Review, 27(5), 462-476. DOI 10.1108/EBR-03-2013-0046

Sealy Singapore extends support to Ronald McDonald House Charities. (2019, April 2). Facebook @Sealy Singapore. Retrieved from https://www.facebook.com/page/271473621807/ search?q=ronald $\% 20$ mcdonald

Sokhela, P. (2015). Brand personality perceptions of luxury sedan motor vehicles amongst the South African generation Y cohort. (Master Dissertation, North West University, Potchefstroom, South Africa). Retrieved from https://dspace.nwu.ac.za/handle/10394/14725

Sweeney, J., \& Brandon, C. (2006) Brand personality: Exploring the potential to move from factor analytical to circumplex models. Psychology and Marketing, 23, 639 - 663. Retrieved from https://doi.org/ 10.1002/mar.20122

Thankyou @melaney_ricardo for choosing Sealy Posturepedic ${ }_{-}$for \#AbubaKids. (2020, November 25). Instagram @Sealy Indonesia. Retrieved from https://www.instagram.com/p/CIA0cFULkPI/

The World Bank. (2020, January 30). Aspiring Indonesia: Expanding the Middle Class. Retrieved from https://www.worldbank.org/en/country/indonesia/publication/aspiring-indonesia-expandingthe-middle-group

What is Sealy Posturepedic? (n.d.). Sealy Posturepedic. https://www.sealy.co.id/what-is-sealyposturepedic

Why Sealy Posturepedic. (n.d.). Sealy Posturepedic. Retrieved from https://www.sealy.com.au/why_sealy 